\title{
Kampüs Öğrencilerinin Eşzamanlı Uzaktan Eğitimde Karşılaştıkları Sorunlar
}

\author{
Ömer Kırmac1 ${ }^{1}$, Sami Acar ${ }^{2}$ \\ ${ }^{1}$ Uzaktan Eğitim Uygulama ve Araştırma Merkezi, Kırklareli Üniversitesi, Kırklareli, Türkiye \\ ${ }^{2}$ Bilgisayar ve Öğretim Teknolojileri Eğitimi Bölümü, Ĕgitim Fakültesi, Gazi Üniversitesi, Ankara, Türkiye
}

Sorumlu Yazar: Ömer Kırmacı, kirmaciomer@gmail.com

Makale Türü: Araştırma Makalesi

Bilgilendirme: $\mathrm{Bu}$ çalışma 5. Uluslararası Öğretim Teknolojileri ve Öğretmen Eğitimi Sempozyumunda sözlü bildiri olarak sunulmuştur.

Kaynak Gösterimi: Kırmacı, Ö., \& Acar, S. (2018). Kampüs öğrencilerinin eşzamanlı uzaktan eğitimde karşılaştıkları sorunlar. Eğitimde Kuram ve Uygulama, 14(3), 276-291. doi:10.17244/eku.378138

\section{The Problems of Campus Students in Simultaneous Online Distance Education}

\author{
Ömer Kırmaci ${ }^{1}$, Sami Acar ${ }^{2}$
}

${ }^{1}$ Distance Learning Implementation and Research Center, Kirklareli University, Klrklareli, Turkey

${ }^{2}$ The Department of Computer and Instructional Technologies Education, Faculty of Education, Gazi University, Ankara, Turkey

Corresponding Author: Ömer Kırmacı, kirmaciomer@gmail.com

Article Type: Research Article

Acknowledgement: This article was presented as oral presentation at the 5th International Conference on Instructional Technologies and Teacher Education.

To Cite This Article: Kırmacı, Ö., \& Acar, S (2018). Kampüs öğrencilerinin eşzamanlı uzaktan eğitimde karşılaştıkları sorunlar. Eğitimde Kuram ve Uygulama, 14(3), 276-291. doi:10.17244/eku.378138 
2018, 14(3), 276-291

\title{
Kampüs Öğrencilerinin Eşzamanlı Uzaktan Eğitimde Karşılaştıkları Sorunlar
}

\author{
Ömer Kırmac1 ${ }^{1}$, Sami Acar ${ }^{2}$ \\ ${ }^{1}$ Uzaktan Eğitim Uygulama ve Araştırma Merkezi, Kırklareli Üniversitesi, Kırklareli Türkiye \\ ORCID: https://orcid.org/0000-0002-0954-1263 \\ ${ }^{2}$ Bilgisayar ve Öğretim Teknolojileri Eğitimi Bölümü, Eğitim Fakültesi, Gazi Üniversitesi, Ankara, Türkiye \\ ORCID: https://orcid.org/0000-0002-3030-3673
}

\begin{tabular}{|c|c|}
\hline Öz & Makale Bilgisi \\
\hline 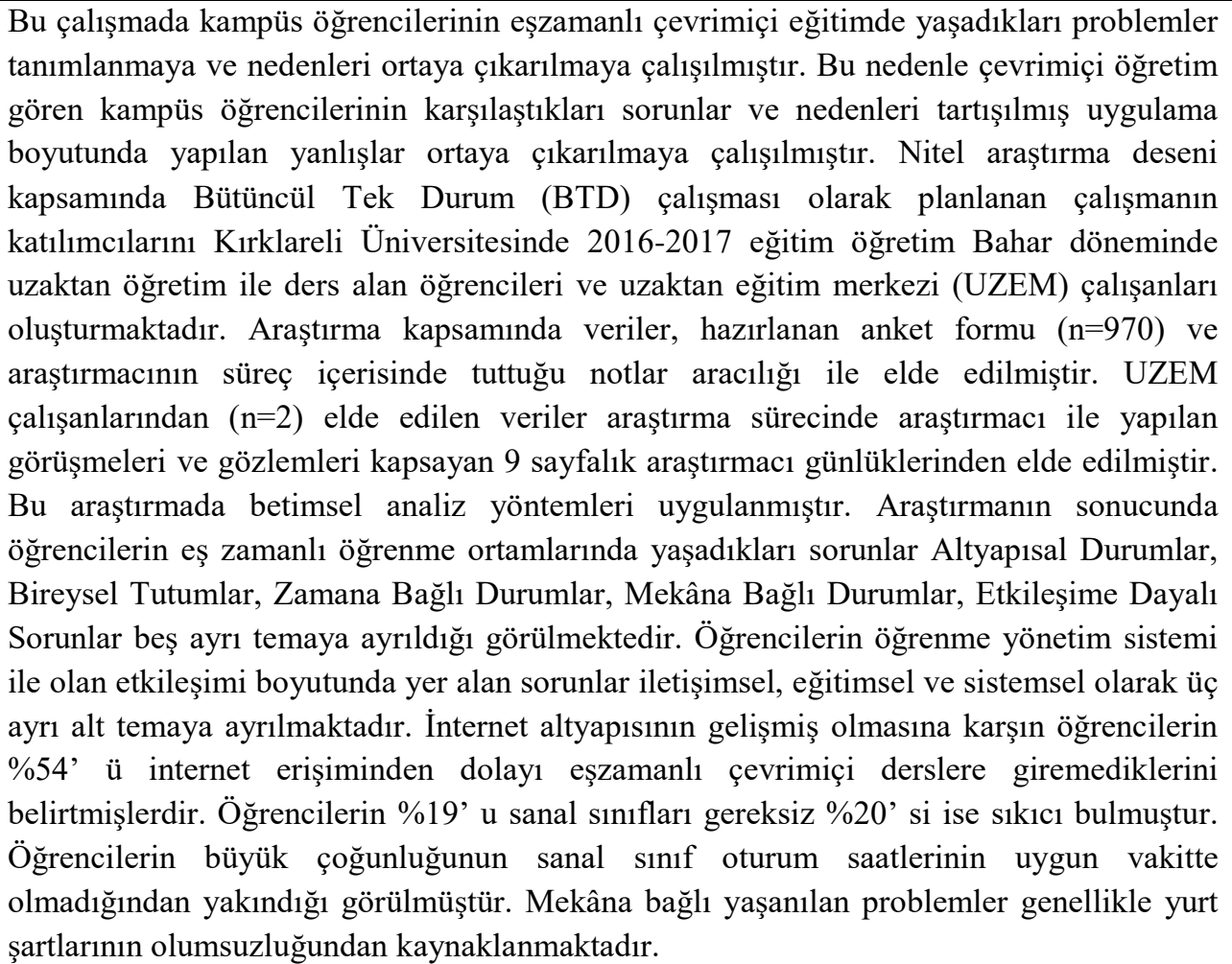 & $\begin{array}{l}\text { Anahtar Kelimeler: } \\
\text { Eşzamanlı uzaktan eğitim, } \\
\text { Ortak dersler, Uzaktan } \\
\text { eğitimde sorunlar } \\
\text { Makale Geçmişi: } \\
\text { Geliş: } 12 \text { Ocak } 2018 \\
\text { Düzeltme: } 25 \text { Mayıs } 2018 \\
\text { Kabul: } 04 \text { Eylül } 2018 \\
\text { Makale Türü: Araştırma } \\
\text { Makalesi }\end{array}$ \\
\hline
\end{tabular}




\section{The Problems of Campus Students in Simultaneous Online Distance Education}

\begin{tabular}{|c|c|}
\hline Abstract & Article Info \\
\hline $\begin{array}{l}\text { This study has been carried out to identify the problems that campus students' experience } \\
\text { in simultaneous online education and to find out the reasons. In addition, the reasons } \\
\text { behind the problems have been discussed and the mistakes made in the implementation } \\
\text { process have been detected. The study was planned as a Holistic Single Case Study within } \\
\text { the qualitative research scope and the participants of the study are the distance education } \\
\text { students of the } 2016-2017 \text { academic year and the employees of the Distance Education } \\
\text { Implementation \& Research Center (UZEM in spring semester in Kirklareli University. } \\
\text { Data for this study were collected using a questionnaire (n=970) and by notes kept by the } \\
\text { researcher during the whole process (Research Diaries). The data collected from UZEM } \\
\text { employees (n= 2) were obtained from 9-page diaries including interviews and } \\
\text { observations conducted by the researcher. In this study, descriptive analysis methods were } \\
\text { applied. As a result of the research, the problems that students have experienced in } \\
\text { simultaneous learning environments have been examined in five different themes: } \\
\text { Infrastructure Situations, Individual Attitudes, Time-Based Situations, Location-Based } \\
\text { Situations, and Interaction-based Problems. The problems in the aspect of the interaction } \\
\text { with the students' learning management system are divided into three sub-themes } \\
\text { communicative, educational and systematically. Despite advanced internet infrastructure, } \\
54 \% \text { of the students pointed out that they could not access online courses because of } \\
\text { internet connection problems. A significant number of students found virtual classes } \\
\text { unnecessary (19\%) and boring ( } 20 \% \text { ). The results of this study show that the vast majority } \\
\text { of students think that the online course starting time is not appropriate. The problems due } \\
\text { to space are usually caused by poor dormitory conditions. }\end{array}$ & $\begin{array}{l}\text { Keywords: Problems of } \\
\text { distance education, Common } \\
\text { courses, Simultaneous online } \\
\text { learning } \\
\text { Article History: } \\
\text { Received: } 12 \text { January } 2018 \\
\text { Revised: } 25 \text { May } 2018 \\
\text { Accepted: } 04 \text { September } 2018 \\
\text { Article Type: Research Article }\end{array}$ \\
\hline
\end{tabular}




\section{Giriş}

Teknoloji ve eğitimin birbiri ile iç içe geçtiği son yıllarda uzaktan eğitim ve öğretim kavramı da teknoloji ile birlikte anılmaya başlanmıştır. Mektup, Radyo, Televizyon derken günümüzde sanal sınıflar hatta sanal gerçeklik öğelerini de içeren ortamlar yaygınlaşmıştır (Moore \& Kearsley, 2012; Simonson, Smaldino, Albright, \& Zvacek, 2014; Veletsianos, 2010). Bu bağlamda uzaktan eğitim, 60' l1 yıllara kadar zaman ve mekân esnekliği söz konusu olmasına karşın (İşman, 2011) çift yönlü iletişim araçları kullanılması ile beraber eş zamanlı uzaktan eğitim dönemi başlamıştır. Böylelikle eş zamanlı etkileşim fırsatı ile zaman esnekliği ikinci planda kalmıştır. Sanal sınıflar, web konferanslar, çevrimiçi ses ve görüntülü iletişim teknolojilerinin yaygınlaşması ile çevrimiçi öğretimde eşzamanlı öğrenme yöntemleri yaygınlaşmıştır. Oturumların kayıt altına alınması imkânı ile dersleri asenkron olarak ta takip edebilmek mümkün olabilmektedir (Ilgaz, 2014; Simonson et al., 2014). Böylelikle ihtiyaca ve uygunluğa göre bireyselleştirilmiş, hayat boyu eğitime olanak sağlayan bir yapı oluşturulabilmektedir. Diğer taraftan mobil cihazların ve internet altyapısının gelişmesi sanal sınıf ortamlarına mobil araçlardan katılım imkânını sağlamış ve daha da esnek bir ortama geçilmiştir. Ancak teknolojik olarak sunulan altyapı ve çeşitli öğrenme araçlarına rağmen bu ortamların etkililiği soru işaretlerine sebep olmaktadır.

Çevrimiçi öğretimin sadece uygun teknolojik ve pedagojik altyapının sağlanması şartı ile verilmesi gerektiği belirtilmektedir (Keegan, 2005; Uşun, 2006). Bu çerçevede uygun bir şekilde doğru şartlar altında uygulandığında çevrimiçi öğretim akademik başarı yönünden örgün yüz yüze öğretimden dezavantajlı olmadığı belirtilmektedir (Moore, 2005; Simonson et al., 2014). Ancak uygulamada özellikle de çevresel yâda bireysel bazı faktörlerin etkisi ile derslere etkin katılamama ve motive olamama durumları çevrimiçi öğretimin belli başlı sorunları olarak belirtilmektedir (Bilgiç, Doğan, \& Seferoğlu, 2011; Ilgaz, 2014; Sümer, 2016; Tuncer \& Taşpınar, 2008; Yükseltürk \& İnan, 2006). Sanal sınıf, telekonferans, videokonferans gibi eş zamanlı ortamlar örgün sınıflarda yer alan etkileşim unsurlarının uyarlanması şeklinde gerçekleştirildiği söylenebilir. Ancak kullanıcı boyutunda yaşanan sorunlar, bu ortamların etkililiği ve verimliliği araştırılması gereken konular arasında yer almaktadır.

Etkileşim eksikliğine dayalı sorunlar çevrimiçi öğretim çalışmalarının sıklıkla üzerine eğildiği bir problem olarak karşımıza çıkmaktadır (Drysdale, Graham, Spring, \& Halverson, 2013; Xiao, 2017). Eş zamanlı çevrimiçi öğretim ortamları etkileşim ve iletişim problemlerine yönelik çözümler üretmesine rağmen süreç içerisinde öngörülemeyen ya da öngörülebilen fakat göz ardı edilen daha başka problemlerin ortaya çıktığı bilinmektedir. Örneğin, Ilgaz (2014), çevrimiçi öğrencilerin sistem kullanımında yönlendirme eksikliği yaşadıklarını belirtmiştir. Sümer (2016) benzer olarak öğrencilerin deneyim eksikliğinden kaynaklanan sorunlar yaşadığı, özellikle deneyim eksikliği olan öğrencilerde örgün öğretimden uzaktan öğretim ortamına geçiş sürecinde uyum sorunu yaşandığ 1 belirtilmiştir. Eş zamanlı derslerde yaşanan iletişim sorunlarına dair öğrenciler arasındaki bireysel farklılıkların ders başarısında önemli rol oynadığı belirtilmektedir (Ilgaz, 2014; Sümer, 2016). Öğrenciler bağlamında karşılaşılan sorunlar için çevrimiçi dersin öğrenci beklentisini karşılamaması (Kuo, Walker, Belland, Schroder, \& Kuo, 2014; Sümer, 2016) ya da öğrencinin aktif katılımının sağlanamaması (Gillet-Swan, 2017) ve öğrencinin sistem dişına çıkması, öğrencinin kendini yalnız hissetmesi, öğrenci bilgisayar okuryazarlığının ve teknik yeterliliğinin düşük olması, öğrenci hazır bulunuşluğunun düşük olması (Dinçer \& Yeşilpınar-Uyar, 2015), canlı derslere düşük katılım (Bailey \& Card, 2009; Dinçer \& Yeşilpınar-Uyar, 2015) ve öğretim elemanı ile öğrenci arasındaki iletişim eksikliği olarak belirtmektedir (Bilgiç \& Tüzün, 2015). Öğretim elemanının teknolojik ve pedagojik yeterliği de sanal oturumların ve uzaktan öğretimin başarısını etkileyen önemli unsurlardan biri olarak belirtilmektedir. (Bilgiç vd., 2011; Darabi, Sikorski, \& Harvey, 2006; Hogan, McKnight, \& Legier, 2006; Kapucu \& Adnan, 2018).

Birçok yükseköğretim kurumunda, 2547 sayılı Yükseköğretim Kanunu'nun 5-i maddesinde belirtilen derslerin (ortak zorunlu dersler olarak ta bilinen Türk Dili, İngilizce, Atatürk İlkeleri ve İnkılap Tarihi) çeşitli nedenlerle uzaktan öğretim yöntemiyle verildiği bilinmektedir. Ancak yüz yüze eğitim alan öğrencilerin (Kampüs Öğrencileri) uzaktan eğitim yoluyla ders almasının bazı sorunları beraberinde getirdiği bilinmektedir. Örneğin uzaktan öğretimin önemli avantajlarından birisi olarak görülen zaman ve mekân esnekliğinin kampüs öğrencileri için önemini yitirdiği belirtilmektedir (Öztaş \& K1lıç, 2017; Sümer, 2016). Bu derslerin zorunlu olarak çevrimiçi verilmesi ise teknolojik yeterliği az olan bölümler için dezavantajlı bir durum yarattığı da söylenebilir (Sakal, 2017). Diğer taraftan sanal sınıf oturumlarının kaydedilip asenkron ders materyali olarak sunulması kaçırılan derslerin izlenebilmesi açısından önemli bir firsat olarak görülmesine karşın birçok yönden suiistimal edilmeye açık bir durum olarak değerlendirilmektedir (Ilgaz, 2014). 
Kampüs öğrencilerinin yaşadığı şehrin olumsuzlukları da çevrimiçi öğretimin niteliğini etkilediği söylenebilir. Genellikle bilgisayar ve internete erişim noktasında yaşanan teknik altyapıya bağlı hız sorunu, elektrik kesintisi, aşırı yüklenme olarak belirtildiği gibi veri tabanında şişmeler, video konferans aksilikleri, görüntü donmaları, teknik sınırlılıklar ve farklı sistemlerin entegrasyonu gibi sorunların yaşandığı belirtilmiştir (Bilgiç \& Tüzün, 2015; Öztaş \& K1lıç, 2017; Sümer, 2016). Diğer taraftan Öğrenme Yönetim Sisteminin (ÖYS) ve sanal sınıf arayüzü tasarımının kullanıcı dostu olmaması veya çalışma yönergesi eksikliğinden kaynaklanan problemler yaşandığı görülmüştür (Dinçer \& Yeşilpınar-Uyar, 2015; Sümer, 2016).

$\mathrm{Bu}$ çalışmada kampüs öğrencilerinin eşzamanlı çevrimiçi eğitimde yaşadıkları problemler tanımlanmaya ve nedenleri ortaya çıkarılmaya çalışılmıştır. Bu nedenle çevrimiçi öğretim gören kampüs öğrencilerinin karşılaştıkları sorunlar ve nedenleri tartışılmış uygulama boyutunda yapılan yanlışlar ortaya çıkarılmaya çalışılmıştır.

\section{Yöntem}

Bu çalışma nitel araştırma yaklaşımlarından Bütüncül Tek Durum (BTD) çalışması olarak desenlenmiştir. Tek bir analiz biriminin yer aldığı ve kendine özgü durumların araştırıldığı durum çalışmalarına bütüncül tek durum çalışması denir (Yin, 2014). BTD çalışmaları; iyi işleyen kuramsal bir sürecin teyit edilmesi ya da çürütülmesi durumlarında ya da genel işleyiş̧e uygun olmayan durumların ortaya çıkarılmasında ya da daha önce çalışılmayan durumların ortaya konulması sürecinde kullanılabilir (Yıldırım \& Şimşek, 2016). Çevrimiçi öğretim uygun koşullarda başarılı sonuçlar verdiği bilinmektedir. Bu çalışmada kampüs öğrencilerinin çevrimiçi öğretim sürecinde yaşadıkları sorunların nedenleri ve gerçekleştirilen uygulama hataları ortaya çıkarılmaya çalışılmaktadır. Her nitel çalışmada olduğu gibi bu çalışmada da durum şartları kendi evreninde değerlendirilmiştir.

\section{Veri Toplama Araçları}

Araştırma kapsamında veriler hazırlanan anket formu ve araştırmacının süreç içerisinde tuttuğu gözlem notlarından elde edilmiştir.

\section{Anket Formu}

Veri toplama sürecinde öğrencilerin çevrimiçi eş zamanlı oturumlarda yaşadıkları problemlerin belirlenmesine yönelik açık ve kapalı uçlu soruların bulunduğu çevrimiçi anket formu hazırlanmıştır. Sorular oturum öncesi ve oturum sürecinde karşılaşılan sorunlar olmak üzere iki kapsam göz önüne alınarak oluşturulmuştur. Böylelikle demografik sorular dişında öğrencilere 10 soru sorulmuştur. Kapsam geçerliliğini sağlamak üzere iki uzman tarafından kontrol edilmiştir. Yapı geçerliliğini sağlamak üzere iki adet dil uzmanı tarafından kontrol edilmiştir. Gelen dönütler çerçevesinde son şekli verilmiştir.

\section{Araştırmacı Günlükleri}

Araştırmacı süreç boyunca gözlemlerini ve informal görüşmelerini araştırmacı günlüğü kapsamında not almıştır. Araştırmacı aynı zamanda uygulama okulunda görev yapmaktadır. Konu ile ilgili deneyimleri ve uygulama okulunda sürdürülen işleyişi araştırmacı günlüklerine yazmıştır. Çalışma kapsamında 6 adet (toplam 9 sayfa) günlük notları bulunmaktadır. Tablo 1 kaydedilen günlükleri göstermektedir.

Tablo 1. Araştırmacı Günlükleri ve Metin İçi Alıntı Gösterimleri

\begin{tabular}{llcc}
\hline & Metin içi alıntı & Tarih & Sayfa Sayısı \\
\hline Araştırmacı Günlüğü 1 & (AG1, 30.03.2017) & 30.03 .2017 & 2 \\
Araştırmacı Günlügü 2 & (AG2, 12.04.2017) & 12.04 .2017 & 1 \\
Araştırmacı Günlüğü 3 & (AG3, 26.04.2017) & 26.04 .2017 & 1 \\
Araştırmacı Günlüğü 4 & (AG4, 10.05.2017) & 10.05 .2017 & 1 \\
Araştırmacı Günlüğü 5 & (AG5, 29.05.2017) & 29.05 .2017 & 2 \\
Araştırmacı Günlüğü 6 & (AG6, 05.06.2017) & 05.06 .2017 & 2 \\
\hline
\end{tabular}




\section{Çalışma Grubu ve Ortamı}

Çalı̧̧ma kapsamında anket formu 2016-2017 Bahar döneminde uzaktan öğretim ile ders alan öğrencilerin tamamına ( $\mathrm{n}=7038$ ) uygulanmıştır. Ankete ulaşabilen toplam 7038 öğrenciden 970' i anketi doldurmuştur. Tablo 2' de ankete katılan öğrencilere ait demografik bilgiler yer almaktadır.

Tablo 2. Öğrencilerin Demografik Bilgileri

\begin{tabular}{cccc}
\hline Değişken & Parametre & f & \% \\
\hline \multirow{2}{*}{ Eğitim Durumu } & Önlisans & 573 & $\% 59$ \\
& Lisans & 379 & $\% 39$ \\
& Diğer & 18 & $\% 2$ \\
\hline \multirow{2}{*}{ Yaş } & $17-19$ & 528 & $\% 54$ \\
& $20-22$ & 383 & $\% 40$ \\
& $23-25$ & 36 & $\% 4$ \\
Cinsiyet & 26 ve Üstü & 22 & $\% 2$ \\
\hline \multirow{2}{*}{ Sanal Ders Oturumuna } & Kadın & 613 & $\% 63$ \\
Katıldıkları Araç & Erkek & 357 & $\% 22$ \\
& Akıllı Telefon & 208 & $\% 62$ \\
& Dizüstü Bilgisayar & 606 & $\% 13$ \\
Sanal Ders Oturumuna & Masaüstü Bilgisayar & 127 & $\% 2$ \\
Katıldıkları Mekân & Tablet Bilgisayar & 15 & $\% 27$ \\
& Ev & 262 & $\% 60$ \\
& Yurt & 586 & $\% 4$ \\
\hline
\end{tabular}

Katılımc1 öğrencilerin büyük çoğunluğunun araştırma üniversitesinin bulunduğu il içerisinde ikamet ettiği söylenebilir. Araştırmaya katılan 970 öğrencinin 913 tanesi uygulama okulunda bir dönemlik uzaktan öğretim deneyimine sahiptir. Dersi tekrar alan öğrencilerin $(n=49)$ deneyimleri iki ve üç dönem olarak belirtilmektedir. Bahar döneminde yeni kayıt olan öğrenciler $(n=28)$ ilk kez uygulama okulunda uzaktan öğretimi deneyimlemiştir.

Araştırmanın diğer katılımcı grubunu ise uzem personeli oluşturmaktadır. Personellerden birisi Öğretim Teknolojileri alanında doktora diğer ise Yüksek Lisans öğrencisidir. Her iki personel uygulama okulunun uzaktan eğitim merkezinin kuruluşundan itibaren (5 yıl) görev yapmaktadır. Bu nedenle kurumlarında yer alan uzaktan eğitim sürecine hâkim oldukları söylenebilir.

\section{Veri Toplama Süreci}

Çevrimiçi anket ÖYS üzerinden tüm öğrencilere uygulanmıştır. Öğrencilere anketi doldurmaları için bir hafta süre verilmiştir ve bir hafta sonunda sistemden kaldırılmıştır. Öğrencilerin anketi rahat ve güvenilir bir şekilde doldurmalarını sağlamak için ders sürecinden bağımsız ve isteğe bağlı bir çalışma olduğu belirtilmiştir.

Anket sürecinde araştırmacı hiçbir şekilde müdahalede bulunmamıştır. Anket sonuçları sistem üzerinden alınıp araştırmacı tarafından incelenmiştir. Veri toplama sürecinin mevcut ders döneminin son zamanlarına gelmesi ile öğrencilerin dönem boyunca yaşadıkları sorunları analiz etme fırsatını yakaladığı ve ankete aktardığı düşünülmektedir. Diğer taraftan açık uçlu soruların yer alması yaşadığı sorunları daha sağlıklı bir şekilde aktarmasına olanak sağlamaktadır. Bu sebeple veri toplama sürecinde veri kaybının az olduğu düşünülmektedir.

\section{Verilerin Analizi}

$\mathrm{Bu}$ araştırmada betimsel analiz yöntemleri uygulanmıştır. Betimsel analizde elde edilen verilen önceden belirlenmiş temalara göre yorumlanır. Genel anlamda nitel veri analizinde betimleme, analiz ve yorumlama olmak üzere üç temel basamaktan bahsedilir (Yıldırım \& Şimşek, 2016). Betimleme basamağında toplanan verilerin hangi sonuçları ortaya koyduğu ve ön plana çıkan sonuçların neler olduğu ortaya koyulmaktadır. Analiz basamağında ise ortaya koyulan verilerde ilk bakışta okunamayan ancak "kodlama", "sınıflama" yoluyla çıkarılan temalar ve temalar arasındaki ilişkilerle nasıl ve neden sorularına verilen yanıtlar ortaya koyulmaktadır (Miles \& Huberman, 2017). Yorumlama ise ortaya çıkan verilerin alanyazında ne anlama geldiğinin araştırmacı tarafından yorumlanması olarak belirtilmektedir. 
Araştırma sürecinde elde edilen veriler çerçevesinde betimsel analiz için tematik çerçevenin oluşturulması ile sürece başlanmıştır. Katılımcıların anket formlarında belirttikleri sorunların niteliğine uygun olarak temalar oluşturulmuştur. Araştırma sürecinde elde edilen anket, açık uçlu sorulardan elde edilen veriler, gözlem notları, informal görüşme notları gibi veriler oluşturulan tematik çerçeveye göre kodlanmış ve sınıflandırılmıştır. Oluşturulan sınıflandırma ve kodlamalardan yorumlamalar yapılmıştır. Yorumlamalar doğrudan alıntılar ve gözlem notları ile desteklenmiştir.

Nitel içerik analizinde katılımcının sorulara verdiği yanıtlar bir bütünlük içerisinde irdelenmelidir (Miles \& Huberman, 2017; Yıldırım \& Şimşek, 2016). Araştırmanın hedefleri doğrultusunda yer alan bir sorunun yanıtı başka bir sorunun altında verilebilmektedir. Özellikle açık uçlu anket formlarında katılımcının cevapları bir bütün olarak incelendiğinde katılımcının çizdiği olay örüntüsü çerçevesinde yordamalar yapılarak aranılan cevaba ulaşılabilmektedir. Bu bağlamda araştırmacıların vardığı bazı yargılara katılımcının diğer sorulara verdiği yanıtlar doğrultusunda çıkarımlar yapılarak ulaşılmıştır. Araştırmada elde edilen kodlamalar birden fazla tema altında yer alabilmektedir.

\section{Bulgular}

Kampüs öğrencilerinin eşzamanlı çevrimiçi öğretimde yaşadığı sorunlar Tablo 3' te görüldüğü gibi beş ayrı temaya ayrılmıştır. Bilgisayar olmaması, bilgisayarın bozuk olması, internet kopması, internete bağlanamama, erişim sıkıntıları gibi sorunlar "Altyapısal Durumlar” teması adı altında toplanmıştır. Öğrencilerin sanal sınıflar hakkındaki sıkıcı, gereksiz gibi düşüncelerini içeren ifadeleri ise "Bireysel Tutum ve Durumlar" teması adı altındadır. Oturumların süresi ve zamanlaması hakkında belirtilen problemler ise "Zamana Bağlı Durumlar" teması altında toplanmıştır. Öğrencilerin oturuma girdikleri ortamlardan kaynaklanan ses, 1şık, gürültü ya da diğer etkenlerin belirtildiği durumlar ise "Mekâna Bağlı Durumlar" teması altında toplanmıştır. Öğrenme Yönetim Sistemi ile öğrencilerin etkileşiminden kaynaklanan sorunlar kategoriye ayrılmıştır. Öğrencilerin oturum saatleri hakkında bilgilendirme eksikliğine bağlı durumlar "iletişimsel”, bilgi eksikliğinden kaynaklanan sorunlar "Eğitimsel Sorunlar" adı altında, Sistemin eksikliğinin dile getirildiği sorunlar ise "Sistemsel Sorunlar" adı altında incelenmiştir.

\section{Altyapıya Bağlı Sorunlar}

Bilgisayar ve internet çevrimiçi öğretimin iki önemli yapıtaşı olmasına rağmen çoğunlukla karşılaşılan sorunlardan birisi olarak dikkat çekmektedir. İnternet altyapısının gelişmiş olmasına karşın öğrencilerin \%54' ü internet erişiminden dolayı eşzamanlı çevrimiçi derslere giremediklerini belirtmişlerdir. Örneğin bir öğrenci bu konuda "Genel olarak bir sıkıntı yaşamıyorum fakat internetin kısıtlı ve yetersiz olması sanal derslere katılmamı güçleştiriyor.”(731 nolu öğrenci) şeklinde durumunu belirtmiştir. Öğrencilerin büyük çoğunluğunun (\%62) dizüstü bilgisayarlara sahip olduğu anlaşılmaktadır. Dizüstü bilgisayarların hem kablolu hem de kablosuz internet bağlantısını sağlayabildiği düşünülünce öğrencilerin en önemli sorununun internet erişimi olduğu varsayılabilir. Diğer taraftan öğrencilerin büyük bir çoğunluğu yurtlarda kalmaktadır (\%60). Yurt internetlerinin basit ağ yapısının çoklu kullanıcı erişimi için yetersiz olduğu bu nedenle öğrencilerin kaldıkları yurt ortamları internet erişimi sağlasa bile bu erişim ancak basit gezinme ve araştırma ihtiyaçlarını karşılayacak kadar olduğu söylenebilir. Bu konuda bir öğrenci "Sanal sınıflar ile ilgili pek bir problemim yok ama yurdun elverişsizliğinden dolayı pek kullanamıyorum. İnternet sıkıntısını çok yaşıyorum. İnternet hızı yavaş...." (511 nolu öğrenci) şeklinde görüş bildirmiştir. Yurtların fiziki imkânlarının da yetersiz olduğu çoğu yurtta bir bilgisayar odasının olmaması sanal sınıf katılımlarını da önemli olarak etkilediği anlaşılmıştır. Bu konuda bir öğrenci "Yurtta bilgisayar yok benimde kendime ait bilgisayarım yok bu yüzden katılamıyorum telefondan da çok uğraştım girmek için ama olmuyo bi türlü....” (615 nolu öğrenci) şeklinde görüş bildirmiştir. Bilgisayarı olmayan öğrenciler akıllı telefonları aracıllı̆ı ile dersleri izleme yoluna gittiği görülmektedir (\%22). Öğrencilerin açık uçlu verdikleri cevaplardan yapılan çıkarımlara göre uygulama ilinin mobil altyapısı sanal sınıf oturumlarına katılmak için verimli bir araç olmadığı öngörülmektedir. Bu konuda bir öğrenci "Sanal sınıfa katılacak bilgisayarım yok telefonum var ama sanal sınıf telefondan açılmıyor izlemek istiyorum lakin benim için en büyük sıkıntı telefondan açılmaması...” (533 nolu öğrenci) şeklinde durumunu belirtmiştir. Bu konuda araştırmac1 gözlemleri ise şu şekildedir "Kırklareli ülkemizin gelişmekte olan şehirlerinden birisidir. Üniversitenin kurulması ile 
bu gelişim hızlanmaktadır. İnternet altyapısının gelişimine yönelik hızlı adımlar atılmaktadır. Ancak üniversite kampüsünün şehrin dışında yer alması ve büyük öğrenci yurtlarının da kampüse yakın olmaması mobil internet konusunda ögrencilere sıkıntı yaratabilir... Öyle ki telefonların çekmediği yerde mobil internetin çekmesi biraz zor gibi...” (AG1-30.03.2017). Bu konuda bir öğrenci ise şu şekilde durumunu belirtmiştir. "Telefonumdan sanal sinıfa girilmiyor. Yurtta internet az çekiyor" (62 nolu öğrenci).

Tablo 3. Eşzamanlı öğrenme ortamlarında kampüs öğrencilerinin karşılaştıkları problemler

\begin{tabular}{cccc}
\hline Temalar & Kodlar & $\mathbf{f}$ & $\mathbf{\%}$ \\
\hline \multirow{3}{*}{ Altyapısal Durumlar } & Bilgisayar, Akıllı Telefon veya Tablet olmaması & 124 & 12 \\
& İnternet erişiminin olmaması & 526 & 54 \\
Bireysel Tutum ve & Eksik yok & 306 & 31 \\
\cline { 2 - 4 } Durumlar & Gereksiz & 179 & 19 \\
& Sikıcı & 187 & 20 \\
& Yetersiz & 127 & 13 \\
\cline { 2 - 4 } Zamana Bağlı Durumlar & Dersler uzun & 148 & 15 \\
& Vakit yetersizliği & 191 & 20 \\
& Dersler Uygun vakitte değil & 356 & 37 \\
\cline { 2 - 4 } Mekâna Bağlı & Evde uygun ortamım yok & 111 & 11 \\
Durumlar & Yurdun fiziki elverişsizliği & 282 & 29 \\
& Yurtta odalar kalabalık & 197 & 20 \\
Sistemsel Etkileşime & Okulda derslere katılabileceğim uygun yer yok & 67 & 3 \\
Dayalı Durumlar & Kullanım bilgisi yetersizliği & 409 & 42 \\
& Bilgilendirme eksikliği & 620 & 63 \\
& Sistemsel eksiklikler & 651 & 67 \\
\hline
\end{tabular}

\section{Bireysel Tutuma Dayalı Sorunlar}

Öğrencilerin anlamlı bir çoğunluğu sanal sınıfları gereksiz (\%19) ve sıkıcı (\%20) bulmuştur. Bazı öğrenciler sıkıc1 bulmasının nedenini gereksiz olması ile bağdaştırdığı görülmüştür. Örneğin, bir öğrenci "Sanal sınıfın hiçbir faydası yok. Sanal sınıfı vakit kaybı olarak görüyorum. E-Dersler de ne varsa sanal sınıfta da aynı şeyler var. Yani ekstra bir bilgi aktarımı yok. Bu açıdan baktığımız da sanal sınıf uzaktan eğitim sistemin de boşuna yer kaplamaktan başka bir işe yaramıyor..." (679 nolu öğrenci) şeklinde görüş bildirirken, bir öğrenci ise sanal sınıfların gereksiz olmasının yanında ders sürelerinin kısaltılmasını çözüm olarak belirtmiştir "e-ders slaytlarını dersi anlamak için yeterli buluyorum. sanal sınıf uygulamasının tek artısı o an soru sorabiliyor olmamız fakat yalnız bunun için bilgisayar başında olmak sıkıcı geliyor. Sanal sınıf etkinliklerinin süreleri kısaltılabilir.” (741 nolu öğrenci). Bazı öğrenciler ise sıkıcı olmasını, gereksiz olmasının yanı sıra teknik sorunlarında neden olduğunu belirtmiştir. Örneğin bir öğrenci "İzlediğim halde tekrar tekrar izlemek zorunda kalıyorum bilgisayarım çoğu zaman sanal sınıfları açmıyor bir sürü program yüklediğim halde, desteklemiyor.” (271 nolu öğrenci). Bazı öğrenciler ise sıkıcı olarak gördüğü sanal sınıfların etkileşim açısından gerekli olduğunu ancak amaca yönelik net ve anlaşılır olmak üzere kısa tutulması durumunda bu durumun aşılacağını belirtmiştir. Bu konuda bir öğrenci "Sanal derslerde sadece sınav hakkında bilgiler verilirse daha çok katılım ve ilgi olacağını düşünüyorum sanal derslerde olan şeyler e-derslerde de var bence" (611 nolu öğrenci). Bu durumu destekler nitelikte başka bir öğrenci ise sanal sınıfları sınavlar hakkında bilgi almak amacı ile izlediğini şu şekilde belirtmiştir "..........internet üzerinden verilen dersleri sadece sınav haftasından önce izliyorum ve öyle not çıkarıyorum." (506 nolu öğrenci). Ayrıca asenkron dersler ile sanal sınıfların birbirlerinin tekrarı olduğu algısıyla sanal sınıf oturumlarında uygulama ya da pekiştirme çalışmalarının yapılmasının yerinde olacağı görüşü de savunulmuştur. Bir öğrenci bu konuda “...Derslerin sanal dersleri yerine daha çok soru çözme imkânı olsa konunun anlaşılması için daha iyi olur.”(264 nolu öğrenci). Diğer taraftan sanal derslerin içerik olarak yetersiz olduğuna yönelik "Yetersiz ve hiçbir kaynak yok izleyerek bişeyler anlayamıyorum" (162 nolu öğrenci) gibi ya da öğretim yöntemi açısından yetersiz olduğuna yönelik "Sanal dersler bence bizim bu dersleri öğrenmemize yeterli değil ....." (518 nolu öğrenci) gibi görüşler de belirtilmiştir. Bu gibi görüşler öğrencilere sunulan içeriğin niceliği ve niteliği konularını akla getirmektedir. Bu konuda uygulama okulunda ki sürece yönelik araştırma günlüklerinde "uzaktan öğretim kapsamında öğrencilere sanal sınıflar (senkron dersler), e-dersler (asenkron) ve çalışma dökümanları sunulmaktadır......... Ancak sanal sınıf oturumlarında bazı öğretim elemanlarımız sunum yüklememekte düz anlatım ile derslerini sürdürmektedir.” (AG2- 12.04.2017) şeklinde bir kesit yer almaktadır.

\section{Zamana Bağlı Sorunlar}

Öğrencilerin zamana bağlı yaşadığı problemler; oturumların uygun vakitte olmaması $(n=356, \% 37)$, öğrencilerin vakitlerinin olmaması $(n=191, \% 20)$, ders sürelerinin uzun olması $(n=148, \% 15)$ şeklinde üç alt kategoride toplandığ 1 
gözlemlenmiştir. Öğrencilerin büyük çoğunluğunun sanal sınıf oturum saatlerinin uygun vakitte olmadığından yakındığı görülmüş̧ür. Bununla ilgili bir öğrenci “en büyük etken benim için saati uygun vakitlerde değil” (928 nolu ögrenci) şeklinde görüş bildirmiştir. Sanal sınıf oturum saatlerinde öğrencilerin kampüs içerisinde bulunmaları diğer bir deyişle oturum saatlerinin öğrencilerin örgün ders vakitlerinde olması en büyük problem olarak görülmektedir. “okuldaki ders saatimle uyuşmadı̆̆ için katılamıyorum” (249 nolu öğrenci), “......sanal derslerin normal derslerle saatlerinin birbirine yakın olmasından dolayı sıkıntılar yaşıyorum”( 176 nolu ögrenci)). Bu konu ile ilgili olarak araştırmacı gözlemleri şu şekildedir "ortak derslerde yürütülen sanal sınıflara ögrrencilerin katılımını sağlamak için haftalık aynı dersi gündüz ve akşam olmak üzere iki oturum şeklinde yapılmaktadır.” (AG2-12.04.2017). Bu gözlemden yola çıkarak öğrencilerin katılamadıkları oturumlar için başka alternatif oturumların olduğu çıkarımı yapılabilir. Ancak bazı öğrencilerin bir işte çalıştığı bu nedenle okul saatleri dışında işte olduğu belirtilmektedir. Bu konuda "Sanal sinıflara katılmaya çalışıyorum ama işten geç çıktığım için zamanında katılamıyorum" (231 nolu ögrenci), "hem okul hem is kosturmaktan pek fazla vakıt bulamıyorum" (629 nolu öğrenci) görüşleri belirtilmiştir. Bu durum öğrencilerin sanal sınıf oturumları için ayrıca bir vakit ayıramadıkları sonucunu ortaya çıkarmaktadır. Öğrenciler sadece okul saatlerinde derslere vakit ayırabildiklerini bu nedenle de okul dışı vakitlerde farklı nedenlerden dolayı sanala sınıfa vakit ayıramadıklarını bildirmişlerdir. Bir öğrenci bu konuyla ilgili olarak "dersler uygun saatte ama benim vaktim yok....” (775 nolu ögrenci) başka bir öğrenci ise "saatleri ayarlayamıyorum” (213 nolu öğrenci) şeklinde sanal sınıflar için ayrıca vakit ayıramadığını bildirmişlerdir. Bazı öğrencilerin uzak yerleşimlerde yaşamasından dolayı yol sürelerinin uzun sürdüğü ve oturumlara yetişemediği belirtilmiştir örneğin "Sanal sinıflarla ilgili bir problem yaşamıyorum sadece merkez dışında oturduğum için canlı katılımlara yetişemiyorum onun dışında bir problem yok..." (619 nolu ögrenci). Katılımc1 öğrencilerin oturum sürelerinden yakındıkları da görülmektedir (\%15). Bu konuda “....Sanal sinıf etkinliklerinin süreleri kısaltılabilir.” (741 nolu öğrenci) olarak görüş bildirilmiştir. Sanal ders oturumlarının süresi ile ilgili görüş bildiren öğrenciler genellikle dersin sıkıcı olması ile bağdaştırmışlardır. Diğer taraftan vakit yetersizliği ve sanal sınıflara bu sebeple fazla vakit ayıramamaktan dolayı oturumların kısaltılması önerisi de sunulmaktadır. Diğer bir deyişle sanal sınıf oturumlarının uzunluğu diğer kodlamaların altında bir çözüm önerisi olarak karşımıza çıkmaktadır.

\section{Mekâna Bağlı Sorunlar}

Öğrencilerin büyük bir çoğunluğu yurtlarda kalmaktadır (\%60). Bu sebeple çevrimiçi senkron derslerde yaşadıkları problemler genellikle yurt şartlarının olumsuzluğundan kaynaklanmaktadır. Altyapısal sorunların yanında kişi sayısının çokluğu derslere katılımı ve verimini düşürdüğü anlaşılmaktadır. Bu konuda bir öğrenci “....Birdaha belirtmeliyim ki yurt cok kalabalık ve gürültülü insanı derslerden çok soğutuyor.” (12 nolu öğrenci) şeklinde görüş bildirmiştir. Diğer taraftan yurtların elverişsiz ortamına yönelik başka bir öğrenci sorununu "Sorun sizden kaynaklı değil kaldiğim yurtta bilgisayar odası yok ayrıca......"(178 nolu ögrenci) olarak belirtmiştir. Diğer taraftan fiziki şartların yanında arkadaş ortamının derse katılımı etkilediğine yönelik "Yurtta kaldığım için arkadaş ortamı yüzünden ders çalışamıyorum." (568 nolu ögrenci) örnek olarak verilebilir.

\section{Sistemsel Etkileşime Dayalı Sorunlar}

Öğrencilerin öğrenme yönetim sistemi ile olan etkileşimi boyutunda yer alan sorunlar iletişimsel eğitimsel ve sistemsel olarak üç ayrı alt temaya ayrılmıştır.

\section{İletişimsel}

Sanal sınıf oturumlarına katılımın düşük olmasının nedenleri arasında öğrencilerin canlı sınıf saatlerinden haberlerinin olmaması olarak görülmektedir (\%63). Öğrencilerden bazıları “.... Sanal sınıfların saatinden haberim olmuyor.” (509 nolu ögrenci; 671 nolu ögrrenci) doğrultusunda görüşlerini dile getirmiştir. Öğrenme Yönetim Sisteminin sanal sınıfların saatleri ile ilgili yeterli uyarılarda bulunmadığını dile getiren öğrenciler de bulunmaktadır (\%23). Örneğin "Sadece gün ve saatler ile ilgili sistem uyarısı yetersiz." (155 nolu öğrenci) şeklinde bir öğrenci görüş bildirmiştir. Uygulama okulunda her öğretim elemanı sanal sınıf oturumlarını genellikle aynı saatlerde yapmaktadır (AG212.04.2017). Ancak oturum saatleri haftalık ders programında belirtilen saatlerden farklı olarak görülmektedir. Bu durum öğrenciler açısından kafa karışıklığına sebep olmuş olabilir. Diğer taraftan öğrencilerin ders öğretim elemanları 
ile yetersiz iletişimi ders saati bilincinin oluşmamasında önemli bir etken olarak görülmektedir. Öğrenci-Öğretim elemanı iletişimini arttırmak amacı ile belirlenen danışman saatlerine katılımın yok denecek seviyede olması (AG529.05.2017) ise canlı oturumlara katılıma yönelik bilgilendirmelerin bizzat öğretim elemanı tarafından yapılmasını zorlaştırmaktadır. Ancak elde edilen bulgular öğrencilerin öğretim elemanlarının bilgilendirme eksikliğinden (\%8) daha çok ÖYS sisteminin bilgilendirme eksikliğini göstermektedir (\%23). Öğrenciler her zaman ÖYS' ne giriş yapamadıklarını farklı bir iletişim aracı ile bilgilendirmenin yapılabileceğini belirtmektedir. Bu konuda bir öğrenci "Sanal sınıflar için sistem ögrencilere bence bilgilendirme için numaralarına bilgi mesajı verebilir. İnternette sürekli takllmayan biri olarakta sık sık sisteme giremiyorum. Bunların nedenlerinden biri de kaldığım kyk yurdun internef erişiminin yetersiz olması, Yavaş olması eklenebilir. Bilgilendirme mesaji gelse hem belki aktif ögrenci saylsı daha çok artabileceğini düşünüyorum...." (430 nolu öğrenci) ş̧eklinde fikrini belirtmiştir. Bir başka öğrenci aynı konuda “...ders saatleri cep telefonlarımıza mesaj olarak gelsin” (795 nolu ögrenci) şeklinde görüşünü bildirmiştir.

\section{Eğitimsel}

Sistemsel etkileşimi etkileyen en önemli sorunlardan birisi ise ÖYS sistemine yönelik bilgi eksikliği olarak göze çarpmaktadır (\%42). Öğrenciler birebir olarak "bilmiyoruz" ifadesini kullanmamalarına rağmen şikâyet olarak ya da açık uçlu verdikleri cevaplar neticesinde ÖYS kullanımına dayalı bilgi eksikliklerine sahip oldukları belirlenmiştir. Ancak belirlenen bilgi eksiklikleri genel kullanımdan çok teknik detaylar konusunda olduğu görülmektedir. Uygulama okulunda daha önceki senelerde bütün birimlerde ÖYS kullanımına yönelik yüz yüze uyum eğitimlerinin de verildiğini ancak bu eğitimlerin planlaması ve organizasyonunun çok zor olduğu onun yerine uzem sitesinde kullanım kılavuzunun olduğunu ve gerekli olan bütün bilgilerin adım adım anlatıldığ1 pdf dokümanı ve videoların yer aldığ 1 belirtilmektedir (AG5-29.05.2017). Buna rağmen bazı öğrencilerin "Tabletime Perculus uygulamasını indirdim fakat sanal sinıflar açılmıyor." (920 nolu öğrenci) gibi yanlış uygulamaları kurduğu ya da "Derslere telefonumdan katılmaya calisiyorum fakat telefon otomatik olarak perculus adli uygulamaya yonlendiriyor. Ordan da okulun adi olmadigi icin acilmiyor....." (587 nolu ögrrenci) gibi uygulama hataları ile karşılaştıklarını belirtmişlerdir. Uzem personeli kendilerine gelen öğrenci e-postalarının ya da telefonlarının büyük bir çoğunluğunun yanlış ya da eksik bilgiden kaynaklandığını bunun önüne geçmek için web sayfalarından ve ÖYS' den genel duyuru yaptıklarını belirtmektedirler (AG5-29.05.2017).

\section{Sistemsel}

Sistemsel etkileşim teması altında sistemin eksikliklerine dayalı problemler en çok karşılaşılan problem olarak belirtilmektedir (\%67). Öğrencilerin genel olarak bahsettiği problemler sanal sınıfların açılmaması, açılırken hata vermesi, donması olarak belirtilmiştir. Bu konuda bir öğrenci "Her bilgisayarda ve telefonda sisteme girilmiyor hata veriyor. Bu durum derslere katılmamı engelliyor." (71 nolu ögrenci) şeklinde görüş bildirmiştir. Bunun yanı sıra etkileşim anlamında sistemin yeterli bilgilendirme araçlarına sahip olmaması durumu öğrencilerin online ders oturumlarını kaçırma haberdar olmama gibi durumlara neden olduğu belirtilmektedir. Bu konuda bir öğrenci sistemin sanal sınıf zamanını bilgilendirme amaçlı araçlarını "Sadece gün ve saatler ile ilgili sistem uyarısı yetersiz." (155 nolu öğrenci) ş̧eklinde görüş bildirerek yetersiz bulmaktadır. Aynı görüşte olan başka bir öğrenci ise "Dersler hakkında online bildirim gelmemesi büyük eksiklik. Örneğin yeni ders eklendiğinde tarayıcının bir köşsesinde küçük bir pencere şeklinde bildirim gelebilir. Bu bize dersleri hatırlamamızda çok yardımcı olabilir. Örneğin Facebook bildirimleri bilgisayar internet ă̆ına bă̆lanır bağlanmaz să̆ alt köşede günlük bildirimler beliriyor. Bunun gibi bir eklenti çok faydalı olabilir” (148 nolu öğrenci) şeklinde görüş bildirmiştir. Bazı öğrenciler sistemsel sorunların çokluğundan dolayı derse harcanması gereken zamanın bu sorunların çözümüne harcandığını bu nedenden dolayı ise dersin verimliliğinin önemli ölçüde azaldığından bahsetmişlerdir. Bir öğrenci "sanal sinıflarda dersten çok sorunlar konuşulduğu için dersin aklşı bozuluyor 20 dk ders için 1 saat vakit kaybediyoruz buda sıkıcı oluyor" (855 nolu ögrenci) şeklinde bu konudaki görüşünü dile getirmiştir. Aynı konu çerçevesinde araştırmacı günlüklerinde yer alan kesitte ise öğretim elemanlarının aynı konudan muzdarip oldukları dersin ilk yarısının ses, görüntü gibi araçların düzgün çalışıp çalışmadığı ile ilgilendiklerini belirtmişlerdir.

\section{Tartışma}

$\mathrm{Bu}$ çalışmada kampüs öğrencilerinin uzaktan eğitim deneyimlerinde yaşadıkları sorunlar tespit edilmeye çalışılmıştır. Altyap1 sorunları çevrimiçi öğretimin başlangıcından bu yana süre gelmekte olan bir problem olarak karşımıza çıkmaktadır. Çevrimiçi öğretimde sadece bilgisayarların kullanıldığı yıllarda bilgisayarların pahalı olması öğrencilerin 
erişimini önemli ölçüde kısıtlamaktaydı bu nedenle öncelikli sorun bilgisayara erişim olarak görülmekteydi. Ancak günümüzde masaüstü bilgisayarlara alternatif araçların (akıllı telefon, tablet, dizüstü bilgisayar) yaygınlaşması çevrimiçi öğretime erişebilecek araç bağlamından ziyade internete erişim konusunda sorunun kaldığ söylenebilir. Bu çalışmada da öğrencilerin genellikle internet erişimi sıkıntısı ya da sağlıklı bir internet erişimine sahip olmaması olarak öne çıkmaktadır. Özellikle öğrencilerin \%62 lik kısmının dizüstü bilgisayara sahip olması yükseköğretim öğrencilerinin bilgisayara ulaşamama sorununun azaldığını göstermektedir. Öğrencilerin yaşadıkları mekânın internete erişimi önemli ölçüde etkilediği görülmektedir. Sisteme erişememe ya da kullanımdan kaynaklanan problemler öğrencilerin çevrimiçi öğretimden soğumasına ve bırakmasına neden olabilmektedir (Lee \& Choi, 2011). Çoğu öğrencinin yurtlarda kaldığı ve yurtların internet altyapılarının ise elverişsiz olduğu görülmektedir. Bilgisayar ve internet erişimi gibi altyapısal sorunlar öğrencilerin sorumluluğunda olması gerektiği kurumların bu sorunu üstlenmesinin mümkün olmadığı kurumlar arasında yaygın bir tutum olarak görülmektedir. Ancak örgün öğrencilere verilen zorunlu uzaktan derslerde öğrencilerin bu gibi altyapısal sorumlulukları kurumdan bekleme algıs1 oluşmaktadır. Bu konu ile ilgili öğrenciler "benim bilgisayar sıkıntım yok internet sıkıntım var bazı arkadaşlarımın bilgisayarı yok kimseye imkanı sorulmadan bu yapılması mantıksı çoğu bilgisayarı alamıyor ya da evdekiler almıyor ders çalışmaz diye bu da bir sebep yılın başında bir anket yada bir duyuru yapılması gerek” (638 nolu öğrenci) şeklinde örgün bir okul tercihinde bulunduklarını, kaldıkları yurdun altyapısal sorunları olduğunu ve bu sorunların kendilerinden kaynaklanmadığını savunabilmektedirler. Simonson ve diğerleri (2014), eşitlik kuramında uzaktan öğretim ile yüz yüze öğretim ortamlarının eşit ortamlardan ziyade birbirine eş değer öğrenme ortamları olarak hazırlanması gerektiğini vurgulamıştır. Bu bağlamda kurumlar yüz yüze ortamlarda yaşanabilecek öğrenme deneyimlerinin uzaktan öğretim ortamlarına aktarılması gibi durumlardan sorumludur. Diğer taraftan uzaktan öğretim yaklaşımında hayat boyu öğrenme, eğitimde firsat eşitliği gibi öğretimin bireyselleştirilmesi düşünceleri yatmaktadır (İşman, 2011; Moore \& Kearsley, 2012; Simonson et al., 2014; Uşun, 2006). Bu eğitim düşüncelerinin temelinde gönüllülük ve bireysel tercihler ön plana çıkmaktadır. Bu nedenle uzaktan eğitimin temelinde gönüllülük esasına dayalı bir tercih hakkı yattığı söylenebilir.

Bireysel tutum boyutunda öne çıkan sorunların en başında sanal sınıfların sıkıcı olması gelmektedir. S1kıcı olması nedenlerinden birisi de eş zamanlı oturumların gereksiz olduğunu düşünmeleridir. Horton (2006), eş zamanlı oturumların öğrencilerin soru sorma potansiyelinin olduğu, asenkron ders materyali hazırlanacak şartların olmadığı, tartışma ortamının gerekli olduğu durumlarda yapılmasının uygun olduğunu belirtmiştir. Uygulama okulunda asenkron ders materyalleri sanal sınıf oturumları birlikte verilmektedir. Öğrenciler bu durumu bilgi tekrarı olduğu gerekçesi ile gereksiz bulduklarını belirtmişlerdir. Oturumlarda verilen bilgilerin sanal sınıfta tekrar edildiği ve öğrencilerin dersi tekrar izleme olanakları düşünüldüğünde sanal sınıf oturumuna katılmak konusunda öğrencilere hak verilebilir. Soruların e-posta yoluyla, ÖYS üzerinde mesaj atılarak ya da diğer iletişim kanallarını kullanarak sorulması öğrenciler için yeterli geldiği söylenebilir. Derse düzenli katıldığını belirten öğrencilerin ise sıkıcı bulması soru sormak için geçirilen emeğin değmeyeceğini belirtmeleri bu düşünceyi güçlendirmektedir. Diğer taraftan öğrencilerin sanal sınıf ortamında anlık soruların zamanı geçmeden yazarak sorulması, sesli tartışma ortamının olmaması gibi etkenler öğrencilerin soru sorma isteğine ket vurabilmektedir (Horton, 2006; Ilgaz, 2014). Katılım, her türlü eğitim yapısında zorunlu bir olgudur (Simonson et al., 2014). Sanal sınıf aktivitelerinde bulunma bire-bir etkileşim firsatı açısından önemlidir. Ancak öğrenmeye yardımcı olması bağlamında en önemli katılım derste bulunmanın yansıra aktif katılım olarak görülmektedir (Lehman \& Conceição, 2010). Diğer taraftan Oturum saatlerinden haberlerinin olmaması öğrencilerin iletişimden kaynaklanan sorunlarından bir tanesi olarak görülmektedir. Oturum saatlerinin öğrencilere iletilmesi ile ilgili en yaygın görüş cep telefonlarına gelen kısa mesaj ya da sosyal medyadan uyarının yapılması şeklinde belirtilmektedir. Ziden, Rosli, Gunasegaran ve Azizan (2017), mesaj bildirimlerinin öğrencilerin oturum saatlerini hatırlatma konusunda faydalı olduklarını ve katılımı sağladıklarını belirtmiştir. Ancak kitlesel açık derslerde her öğrenciye her bir oturumun mesaj servisi ile uyarı verilmesi maliyet yönüyle uygulanabilir bir çözüm olmadığı öngörülebilir. Diğer taraftan öğrencilerin örgün derslere katılımında aldığg sorumluluğu uzaktan öğretim derslerinde de alması gerektiği belirtilmektedir (Boettcher 2011; Lehman \& Conceição, 2010; Simonson et al., 2014). 
Örgün derslerin uzaktan verilmesi öğrencilerin okul saatlerinde kampüs içerisinde olması sorununu beraberinde getirmiştir. Uzaktan öğrenme temel olarak bir şekilde öğretim sistemi dişında kalmış bireylerin tekrar sisteme kazandırılmasını hedeflemektedir. Ancak bazı sınırlılıklardan (derslik, öğretim elemanı, bütçe) dolayı kurumlar uzaktan öğretimi seçmek zorunda kalabilmektedirler. Böylelikle örgün olarak öğrenim gören kurum ile aynı lokasyonda bulunan öğrenciler uzaktan öğrenme ile internet üzerinden dersleri takip etmektedirler. Bu bağlamda öğrencilerin, öğretim elemanlarının ve yöneticilerin örgün ve uzaktan dersler arasında bir denge kurmaları gerekmektedir. Özellikle zamana ve mekâna bağlı sorunların büyük bir çoğunluğu bu dengenin kurulamamasından kaynaklandığı görülmektedir. Zaborova, Glazkova ve Markova (2017), öğrencilerin iş ve okulu aynı zamanda yürütebildikleri takdirde uzaktan öğretimin başarılı olabildiğini belirtmiştir. Bu bağlamda özellikle örgün öğrencilere verilen uzaktan öğretim derslerinin öğrencilerin diğer (örgün) derslerle ya da iş durumları ile zaman ve mekân dengesinin kurulması gerekmektedir. Simonson ve diğerleri (2014), ders planlayıcıların öğrencilerin durumlarının farkında olması gerektiğini ve buna yönelik önlemler alması gerektiğini belirtmişlerdir. Örneğin öğrencilerin teknik ve de oturuma yetişememe gibi sorunların çözülebilmesi için oturumu belirli bir süre önce başlatmasını bu süre zarfında yeni konu anlatımının dışında katılan öğrencilerin sorularına yanıt vermesinin faydalı olabileceğini savunmuşlardır. Yaşanan bu denge kurma karmaşasında ise öğrenme başarısının gerçekleşmesi ise öğrencilerin oturumdaki aktif katılımına endeksli olacağı söylenebilir. Diğer taraftan öğrencilerin öz-düzenleme becerilerinin özellikle de planlama becerisinin uzaktan öğretimde başarı ve memnuniyet açısından belirleyici bir etken olduğu belirtilmektedir (Inan, Yükseltürk, Kuruçay, \& Flores, 2017). Ancak öğrencilerin okuldaki diğer derslerin koşuşturmacasında sanal oturumlara canlı katılım için altyapı ve fiziki şartların ve zamanlamanın ayarlanması gibi konulardan yakındıkları ve derse aktif katılımdan daha çok devamsızlık sorununu gidermek için sadece oturumda bulunmayı ön plana koydukları söylenebilir (Demirkan, Bayra, \& Baysan, 2016; Zaborova, Glazkova, \& Markova, 2017). Buna rağmen özellikle canlı katılım oranı öğretim elemanlarının en çok yakındığı durum olarak belirginleşmektedir (AG4, 10.05.2017; Bilgiç \& Tüzün, 2015; Sümer, 2016). Öğrencilerin değerlendirme odaklı uzaktan öğretim sistemine girmeleri diğer bir deyişle dersten geçmeye yönelik davranışlarda bulunması derse katılımı önemli oranda etkilemektedir. Bu duruma yönelik sanal sınıf oturumu sürecinde aktif katılımı sağlamaya yönelik aktiviteler (Bilgiç \& Tüzün, 2015, Pallof \& Pratt, 2009) planlanarak öğrencilerin hem öğrenme süreci desteklenebilir hem de dersin sıkıcı durumu giderilebilir (Sümer, 2016).

Diğer taraftan çevrimiçi ortam akademik boyutunun yanında öğrenciye ve diğer paydaşlara teknolojik yeterlilik sorumluluğunun sürekli olarak yüklendiği bir ortam olarak sunulmaktadır (Gillett-Swan, 2017). Bu bağlamda öğrenciler itiraf etmeseler de bilgi eksikliğine dayalı bazı problemler yaşadıkları belirlenmiştir. Genel olarak teknik konulara dayalı olarak belirlenen bu problemler sanal sınıf uygulamasının mobil telefon uyumundan kaynaklandığı göze çarpmaktadır. Uzaktan öğretim öğrencilerine verilen uyum eğitimleri çerçevesinde hazırlanan eğitim materyallerinin ise erişime kolay yerde olması (Ilgaz, 2014) öğrencilerin problem yaşadığı durumlarda kolayca faydalanabilmesi açısından önemli olarak görülmektedir. Uygulama okulunda uzaktan öğretim merkezinin sitesinde ve ÖYS içerisinde uyum eğitimi videolarının yer aldığı belirtilmektedir. Ancak anket ve öğrenci kodlamalarında öğrencilerin bu materyallere ulaşıp ulaşamama durumlarına ait veriye ulaşılmamıştır. Araştırmada bilgi eksikliğine ya da hatalı bilgiye dayalı sorunlar ögrencilerin şikâyet yazılarından ve uzem personeli ile yapılan görüşmelerden ortaya çıkarılmıştır. Öğrencilerin bilgiye dayalı sorunlarının farkında olmaması ise ayrıca düşünülmesi gereken bir konu olarak dikkat çekmektedir.

\section{Sonuç ve Öneriler}

Çevrimiçi öğretim; öğretim elemanı, derslik, öğretim programı vb. konularda kurumlara maliyet açısından birçok avantaj sağladığı için tercih edilmektedir. Diğer taraftan İnternet altyapı maliyetlerinin düşmesi, ÖYS hizmetlerinin niteliklerinin artması gibi unsurlar çevrimiçi öğretim uygulamalarının yaygınlaşma sürecini hızlandırmış ve yaşanan bazı sorunların çözümünü kendiliğinden sağlamıştır. Örneğin sanal sınıfların gün geçtikçe yaygınlaşması etkileşim sorununa bir çözüm getirmiş; sanal sınıfların kayıt edilmek suretiyle asenkron olarak hizmete sunulması oturumu kaçıran öğrenciler için yeni bir firsat yaratmıştır. Sanal sınıflar, çevrimiçi öğretimde etkileşim gibi önemli bir sorunun çözümü için firsat sunmakla beraber, bu sınıflara katılım oranlarının düşük düzeyde kalması başka bir takım problemlerin varlığını akla getirmektedir. Özellikle kampüs öğrencilerinin çevrimiçi öğretim ile aldıkları 5-i derslerinde katılım konusunda problemlerin yaşandı̆̆ görülmektedir.

$\mathrm{Bu}$ çalışmada sanal sınıf oturumlarında yaşanan sorunlar kampüs öğrencileri perspektifinden ele alınmıştır. Sonuç olarak öğrencilerin altyapıya dayalı şartlar bağlamında sanal sınıf oturumuna erişebileceği araç (bilgisayar, 
telefon vb.) sıkıntısından daha çok İnternet erişimi sıkıntısı yaşadıkları tespit edilmiştir. Diğer taraftan öğrencilerin büyük bir çoğunluğunun yurtlarda ikamet ettikleri ve yurt ortamlarındaki teknik yetersizliklerden kaynaklanan sorunlardan dolayı sanal sınıf derslerine katılım oranlarının düştüğü tespit edilmiştir.

Ayrıca, sanal sınıf oturumlarına katılımı arttırmak için öğrencilerin sık sık bilgilendirilmesi ve yönlendirilmesi gerektiği belirlenmiştir. Bunu sağlamak için sosyal medya ya da anlık mesajlaşma grupları ideal bir yol olarak önerilebilir. Bu öğrencilerin aynı zamanda örgün derslerinin olması nedeniyle gerekli bilgilendirmelerin okullarda yapılması efektif bir yöntem olarak öne çıkmaktadır. Diğer taraftan ÖYS'de yer alan uyarıcıların ve yönlendiricilerin açık ve net olarak sanal sınıf oturumunun saatini bildirmeleri uygun olacaktır.

Örgün derslerin uzaktan öğretim ile verilmesi okul yönetimi açısından birçok avantaja sahip olmasına karşın özellikle öğrencilerin derslere katılımı konusunda bazı sorunların yaşandığı belirlenmiştir. Öğrenciler özellikle sanal sınıf oturum saatlerinin örgün ders saatleri ile uyumsuz olmasından dolayı sıkıntı yaşadıklarını ifade etmişlerdir. Bunun yanında, çalışma hayatına katılan öğrenciler örgün eğitimdeki ders saatleri dışında işte olduklarından sanal sınıflara yeterli ölçüde katılım sağlayamamaktadırlar. Diğer taraftan, öğrencilerin çevrimiçi öğretimi zorunlu olarak almaları altyapı, zaman ve mekân alanlarında yetersiz öğrenciler için sorun yaşamalarına neden olabilmektedir. Bu tür sorunlar bireysel tutumlara dayalı problemleri de tetiklediği görülmektedir. Bu nedenle bu tür zorunlu derslerin kitlesel açık çevrimiçi dersler (KAÇD) kapsamında asenkron olarak verilmesi altyapı sorununun önüne geçemese bile zaman ve mekâna dayalı sorunları engelleme adına önemli bir adım olabilecektir. 


\section{Extended Summary}

\section{Introduction}

In many higher education institutions, it is known that the courses mentioned in article 5-i of the Higher Education Law No. 2547 (known as common compulsory courses such as Turkish Language, English, Atatürk Principles and History of Revolution) are carried out through the online distance education method for various reasons. However, it has been pointed out that some regular students (known as Campus Students) have had some problems while they were taking distance education classes. It is mentioned that one common problem was the dependency on time and place. For instance, virtual classroom sessions, scheduled daytime hours, were complained about device and place to access by students. However, virtual classroom sessions are recorded and presented as asynchronous course material, which is regarded as a good opportunity to review the missed courses, but it is also considered open to abuse in many aspects.

It can be said that the negative conditions of cities (infrastructure of the internet, electricity etc.) where campus students live affect the quality of distance education. It can be concluded that the disadvantages of distance education affected the campus students living in the city. It has been stated that there are problems such as overload of databases, video conferencing mishaps, image disconnection, technical limitations and the integration of different systems. In addition, it has been observed operational and interaction problems because of not having user-friendly interface of Learning Management System.

In this study, the aim is to identify the problems that campus students experience during simultaneous online education sessions and to find out the reasons. For this reason, this study intends to determine the problems that campus students have while studying online. In addition, the reasons behind the problems have been discussed and the mistakes made in the implementation process have been detected. What are the problems faced by campus students in simultaneous learning environments?

\section{Methodology}

This study is designed within the scope of qualitative research method. It was carried out as a holistic single case study in terms of qualitative research approaches. Within the scope of the research, the data were collected from the questionnaire $(n=970)$ and observation notes kept by the researcher during the whole process. Data obtained from the staff of the distance learning center $(\mathrm{n}=2)$ were obtained from 9-page research diaries, including interviews and observations conducted by the researcher during the process.

The participants of this study are; the students who are studying at Kurklareli University and who take courses through distance education in the Spring semester 2016-2017 academic year and the staff of Distance Education Center (KLUZEM). A total of 970 students, 573 associate degree students (59\%), 379 undergraduate students (39\%) and 18 graduate students $(0,18 \%)$ participated in the survey voluntarily. In addition, staff who are working in the application school have been consulted about the process within the scope of the research.

During the 2016-2017 Spring semester, the data collection process was carried out. The online questionnaire was applied to all students through the LMS. Students were given one week to fill out the questionnaire and were removed from the system after a week. In order to ensure that students can fill in the questionnaire comfortably and reliably without any pressure, it is stated that the aim is to provide better service to the students during the distance education process, which is not related to the course, with the aim of revealing the problems they are experiencing. On the other hand, to valuable information the questionnaire were filled out by the students voluntarily. The questionnaire was sent to 7038 students. 970 out of 7038 students filled in the questionnaire form.

In this study, descriptive analysis methods were applied. The process started with the creation of thematic frameworks for descriptive analysis within the framework of the data obtained during the research process. The themes were determined in accordance with the nature of the problems that the participants described in the questionnaire forms. The questionnaire obtained in the research process is coded and classified according to the thematic framework in which data are given, such as data from open-ended questions, observation notes, and informal interview notes. Interpretations were made from the generated classification and coding. Interpretations were directly supported by quotations and observation notes. 


\section{Findings}

Nowadays, internet and computer infrastructure, which are the two essential components of online distance education have been developed like wildfire, but also still one of the biggest obstacles that we have been confronted in the study. Although the internet infrastructure is developed, $54 \%$ of the students stated that they could not access online courses because of internet connection problems. A significant number of students found virtual classes unnecessary (19\%) and boring (20\%). Some students said it was boring because they found virtual classes unnecessary. Problems related to time were observed in three subcategories: absence of appropriate sessions ( $n=356,37 \%)$, absence of students' time $(\mathrm{n}=191,20 \%)$ and duration of lectures $(\mathrm{n}=148,15 \%)$. A large majority of students reside in their homeland $(60 \%)$. For this reason, the problems they experience in online synchronous lessons are usually caused by the poor conditions of dormitories. Among the reasons for low attendance to virtual classroom sessions is the lack of news from students on live classroom hours (63\%). One of the most important problems affecting the systemic interaction is the lack of information on the LMS system (42\%). Although the students do not use the expression "we do not know" in person, they have been found to have lack of knowledge based on the use of LMS as a complaint or as a result of their open-ended responses. However, it is seen that the determined lack of information is about technical details rather than general usage. Problems based on system deficiencies under systemic interaction is the most common problem (67\%). The problems that students generally face are problems in logging in virtual classes, failing to log in, and freezing.

\section{Conclusion}

In this study, problems in virtual classroom sessions are discussed from the campus students' perspective. As a result, it has been found out that students are more likely to have internet access problems due to the inconvenience of the tools (computer, telephone, etc.) that can access the virtual classroom session in the context of infrastructure. On the other hand, we can say that the vast majority of the students lived in dormitories and this prevented their participation in virtual classroom courses due to problems originating from unfavorable conditions of dormitories.

It can be concluded that students should be informed and guided to participate frequently in virtual classroom sessions. To do this, a social media group or instant messaging groups can be suggested as an ideal way. It can be deduced that students are having difficulties in attending to virtual classroom sessions, although the distance learning courses have many advantages in terms of school management. It can be said that the students were particularly distressed because the virtual classroom session hours were incompatible with the scheduled face to face class hours. On the other hand, it has been seen that students who take these courses through online distance education necessarily cause difficulties for the students with disabilities. Thus, providing such compulsory courses as asynchronous in the context of Massive Open Online Courses (MOOC) may be an important step in preventing time and space-based problems, even if it does not prevent the infrastructure problem. 


\section{Kaynakça / References}

Bailey, K. D. (1982). Methods of social research (2nd ed.). New York: The Free Press.

Bailey, C. J., \& Card, K. A. (2009). Effective pedagogical practices for online teaching: Perception of experienced instructors. The Internet and Higher Education, 12(3), 152-155.

Bilgiç, H. G., Doğan, D., \& Seferoğlu, S. S. (2011). Türkiye'de yükseköğretimde çevrimiçi öğretimin durumu: ihtiyaçlar, sorunlar ve çözüm önerileri. Yükseköğretim Dergisi, 1(2), 80-87.

Bilgiç, H. G., \& Tüzün, H. (2015). Yükseköğretim kurumları web tabanlı uzaktan eğitim programlarında yaşanan sorunlar. Açıöğretim Uygulamaları ve Araştırmaları Dergisi, 1(3), 26-50.

Boettcher, J. V. (2011). Ten best practices for teaching online: Quick guide for new online faculty. http://www.designingforlearning.info/services/writing/ecoach/tenbest.html adresinden 07.07.2017 tarihinde edinilmiştir.

Çelen, F., Çelik, A., \& Seferoğlu, S.S. (2011). Yükseköğretimde çevrimiçi öğrenme: Sistemde yaşanan sorunlar ve çözüm önerileri. Journal of European Education, 1(1), 25-34.

Darabi, A. A., Sikorski, E. G., \& Harvey, R. B. (2006). Validated competencies for distance teaching. Distance Education, 27(1), 105-122.

Demirkan, Ö., Bayra, E., \& Baysan, E. (2016). Uzaktan eğitim öğrencilerinin dersleri tâkip etme durumlarının dönem sonu başarılarına etkisi. Türkiye Sosyal Araştırmalar Dergisi, (1), 47-75.

Dinçer, S., \& Yeşilpınar-Uyar, M. (2016). E-öğrenme sistemlerinin kullanımı sürecinde karşılaşılan sınıf yönetimi ile ilişkili sorunlar ve çözüm önerileri. Kuram ve Uygulamada Egitim Yönetimi Dergisi, 21(4), 453-470.

Drysdale, J. S., Graham, C. R., Spring, K. J., \& Halverson, L. R. (2013). An analysis of research trends in dissertations and theses studying blended learning. The Internet and Higher Education, 17, 90-100.

Erlandson, D. A., Harris, E. L., Skipper, B. L., \& Allen, S. T. (1993). Doing naturalistic inquiry: A guide to methods. Beverly Hills, CA: Sage.

Gillett-Swan, J. (2017). The challenges of online learning: Supporting and engaging the isolated learner. Journal of Learning Design, 10(1), 20-30.

Hogan, R. L., McKnight, M. A., \& Legier, J. T. (2006). Moving from traditional to online instruction: Considerations for improving trainer and instructor performance. The Journal of Human Resource and Adult Learning, 2(2), 34-38.

Horton, W. (2006). E-learning by design. San Francisco, CA: John Wiley and Sons, Inc.

Ilgaz, H. (2014). Uzaktan eğitim öğrencilerinin eşzamanlı öğrenme uygulamalarında karşılaştıkları sorunlar ve çözüm önerileri. Eğitim Bilimleri ve Uygulama, 13(26), 187-201.

Inan, F., Yukselturk, E., Kurucay, M., \& Flores, R. (2017). The impact of self-regulation strategies on student success and satisfaction in an online course. International Journal on E-Learning, 16(1), 23-32.

İşman, A. (2011).Uzaktan eğitim (4. baskı). Ankara: Pegem Yayınevi.

Kapucu, N. K., \& Adnan, M. (2018). Uzaktan öğretimde çevrimiçi eğitmen başarısının değerlendirilmesi. HAYEF: Journal of Education, 15(1), 7-20.

Keegan, D. (2005). Reintegration of the teaching acts. In D. Keegan (Ed.), Theoretical principles of distance education (pp. 100119). New York, NY: Routledge.

Kuo, Y. C., Walker, A. E., Belland, B. R., Schroder, K. E., \& Kuo, Y. T. (2014). A case study of integrating Interwise: Interaction, internet self-efficacy, and satisfaction in synchronous online learning environments. The International Review of Research in Open and Distributed Learning, 15(1), 161-181.

Lee, Y., \& Choi, J. (2011). A review of online course dropout research: Implications for practice and future research. Educational Technology Research and Development, 59(5), 593-618. 
Lehman, R. M., \& Conceição, S. C. (2010). Creating a sense of presence in online teaching: How to "be there" for distance learners (Vol. 18). San Francisco, CA: John Wiley and Sons, Inc.

Moore, J. C. (2005). The Sloan Consortium Quality Framework and the five pillars. http://www.mit.jyu.fi/OPE/kurssit/TIES462/Materiaalit/Sloan.pdf adresinden 03.06.2017 tarihinde edinilmiştir.

Moore, M. G., \& Kearsley G. (2012). Distance education: A systems view of online learning (3rd ed.). Wadsworth, CA: Cengage Learning.

Miles, M. B., \& Huberman, A. M. (2017). Nitel veri analizi. (2. baskıdan Çev. A. Ersoy \& S. Akbaba-Altun). Ankara: Pegem Yayıncılık. (Orijinal yayın yılı 1994).

Öztaş, S., \& Kılıç, B. (2017). Atatürk ilkeleri ve inkılâp tarihi dersinin uzaktan eğitim şeklinde verilmesinin öğrenci görüşleri açısından değerlendirilmesi. Türk Tarih Ĕ̈itimi Dergisi, 6(2), 268-293.

Sakal, M. (2017). Çevrimiçi öğrenmede öğrencilerin hazırbulunuşluk düzeylerinin demografik özelliklerine göre incelenmesi. Sosyal ve Beşeri Bilimler Araştırmaları Dergisi, 18(39), 81-102.

Simonson, M., Smaldino, S., Albright, M., \& Zvacek, S. (2014). Teaching and learning at a distance (6th ed.). Charlotte, NC: Information Age Pub.

Sümer, M. (2016). Sanal derslere ilişkin öğrenci görüşlerinin incelenmesi. Uşak Üniversitesi Sosyal Bilimler Dergisi, 9(3), 181200.

Tuncer, M., \& Taşpınar, M. (2008). Sanal ortamda eğitim ve öğretimin geleceği ve olası sorunlar. Sosyal Bilimler Dergisi, 10(1), $125-144$

Uşun, S. (2006). Uzaktan ĕgitim. Ankara: Nobel Yayınevi

Veletsianos, G. (2010). A definition of emerging technologies for education. In G. Veletsianos (Ed.), Emerging technologies in distance education (pp. 61-87). Edmonton, AB: AU Press.

Xiao, J. (2017). Learner-content interaction in distance education: The weakest link in interaction research. Distance Education, 38(1), 123-135.

Yıldırım, A., \& Şimşek, H. (2016). Sosyal bilimlerde nitel araştırma yöntemleri (10. Baskı). Ankara: Seçkin Yayıncılık.

Yin, R. K. (2014). Case study research: Design and methods (5th ed.). London: Cosmos Publications.

Yükselturk, E., \& Inan, F. A. (2006). Examining the factors affecting student dropout in an online certificate program. Turkish Online Journal of Distance Education, 7(3), 76-88.

Zaborova E. N., Glazkova I. G., \& Markova T. L. (2017). Distance learning: students' perspective. Sotsiologicheskie issledovaniya [Sociological Studies], (2), 131-139. 